\title{
KAJIAN MATAN DAN SANAD HADITS DALAM METODE HISTORIS
}

\author{
Mohamad S. Rahman
}

\section{A. Pendahuluan}

Al-Quran memberikan petunjuk bahwa hadits Nabi Saw adalah salah satu sumber hukum ajaran Islam. Namun karena hadits tidak seluruhnya tertulis pada zaman Nabi Saw., dan proses penghim- punannya memakan waktu yang cukup lama dan kitab hadits jum- lahnya juga cukup banyak, maka hadits Nabi sangat penting untuk dicermati, dikaji dan diteliti, agar dapat dikatakan secara jelas kedudukan hadist tersebut.

Tingkat kebenaran riwayat kedua sumber ajaran Islam tersebut (al-Quran dan hadits) itu menjadi tidak sama, yaitu seluruh tingkat riwa- yat al-Quran adalah qath'iy al-wurud, sedangkan untuk riwayat hadits ada yang qat'iy wurud dan dzanny al-wurud.

Riwayat yang qat'iy wurud sudah pasti terhindar dari kemungkinan salah, sedangkan dzanny al-wurud terbuka kemungkinan salah, dan karena itu diperlukan adanya kajian dan penelitian secara khusus dan cermat serta dapat dipertanggungjawabkan secara ilmiah.

Dalam rangka menjaga kemurnian hadits, para ulama melakukan prosedur penelitian yang ilmiah, sehingga dapat dipastikan bahwa ulama mutaqaddimin merupakan peletak dasar-dasar kaidah penelitian historis yang sangat hati-hati dari seluruh umat manusia di dunia ini. Sehingga upaya yang dilakukan para ulama diperoleh hasil yang murni dalam kajian dan penelitian hadits.

Bagian hadits yang diteliti meliputi matan dan sanad hadits. Penelitian matan tersebut juga dengan kritik matan atau kritik intern. Sedangkan penelitian sanad disebut penelitian ekstern. Untuk akurasi kaidah kri- tik penelitian sanad sangat tinggi, sedangkan untuk penelitian kritik matan tampaknya masih memerlukan pengembangan sejalan dengan perkembangan pengetahuan. Penelitian hadits dari segi sanadnya adalah 
mengambil kesimpulan akhir yang diperoleh dengan cara mempelajari

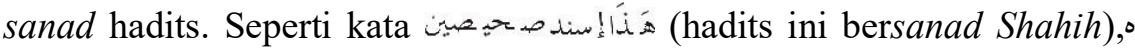

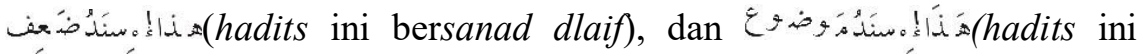
bersanad maudhu'), berdasarkan kaidah-kaidah yang dipraktekkan para ahli ketika meneliti sanad hadits, dengan mengetahui metode yang dipraktekkan. Sedangkan penilaian dari segi matan, selain hal-hal di atas, terdapat hal-hal yang penting lainnya, seperti melihat ada atau tidak syadz atau illat mencatatkan matan, atau matan itu diriwayatkan dengan sanad lain yang menyebabkan nilainya berubah.

Untuk mendapatkan gambaran apa-apa yang akan ditelusuri guna diteliti pada makalah ini, maka yang menjadi permasalahannya adalah sebagai berikut:

1. Apa pengertian sanad dan matan hadits?

2. Bagaimana model penelitian sanad dan matan hadits?

3. Bagaimana perkembangan dan pengaruh sanad terhadap klasifikasi hadits?

\section{B. Pengertian Sanad dan Matan Hadits}

Untuk mempermudah mengenal dan memberikan gambaran tentang sanad dan matan suatu hadits maka akan dikemukakan sebuah hadits yang lengkap sanad, matan dan rawynya yaitu sebagai berikut:

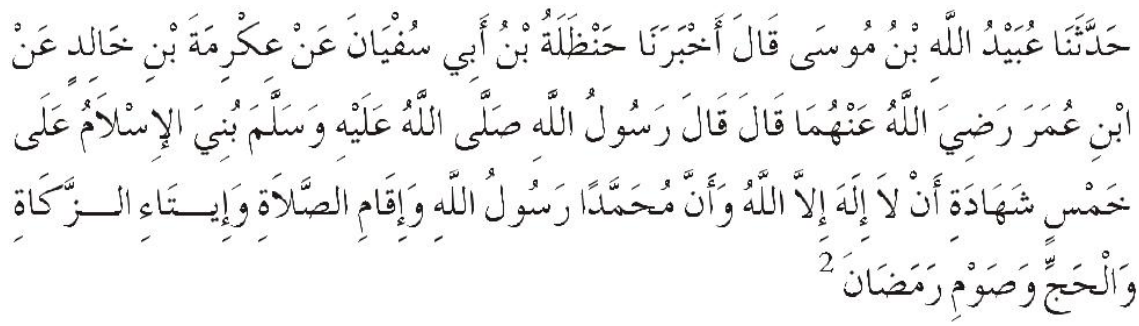

Mahmud al-Tahan, Ushul al-Takhrij wa darasah al-asanid, diterjemahkan oleh Ridwan Nasir dengan judul Metode Takhrij dan Penelitian Sanad Hadits, (Surabaya: PT. Bina Ilmu, 1995), h. 98.

Global Islamic Software Company, al-Hadits al-Syarif, al-isdaruts-tsany, jamiu al-huquqy mahfudzatu lisyirkatial-muramij al-islamiyah aldauliyah, 1991-

1997, Shahih Bukhari, hadits ke-7. 
Telah menceritakan kepada kami Ubaidillah bin Musa berkata: telah mengkhabarkan kepada kami Handzalah bin Abi Sufyan dari Ikrimah bin Khalid dari Ibnu Umar ra., berkata bersabda Rasulullah saw., dibina Islam itu atas lima perkara syahadat bahwa tak ada tuhan selain Allah dan sesungguhnya Muhammad Rasulullah dan mendirikan shalat dan membayar zakat dan berhaji dan berpuasa pada bulan ramadhan (Sha- hih Bukhari hadist ke-7).

Dari gambaran hadits tersebut dapat dikemukakan bahwa ada tiga unsur yang terkandung dalam satu hadits, yaitu sanad, matan, dan rawy. Namun, yang akan dibahas dalam tulisan ini adalah masalah sanad dan matan.

Sanad menurut bahasa berarti sandaran, yang kita bersandar padanya, dan berarti dapat diperpegangi, dipercayai. Sedangkan me- nurut istilah, sanad berarti keseluruhan rawy dalam suatu hadits de- ngan sifat dan bentuk yang ada.

Dari gambaran hadits di atas maka yang termasuk sanad adalah

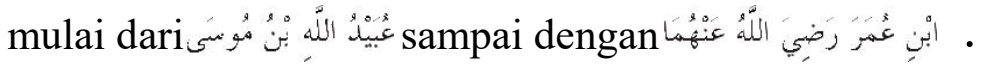

Selanjutnya matan menurut bahasa berarti punggung jalan (muka jalan) tanah yang keras dan tinggi. Sedangkan matan menurut istilah ialah bunyi atau kalimat yang terdapat dalam hadits yang menjadi isi riwayat. Apakah hadits tersebut berbentuk qaul (ucapan), fi'il (perbuatan), dan taqrir (ketetapan dan sebagainya) dari Rasulullah Saw.

Berdasarkan hadits di atas, yang termasuk kategori matan

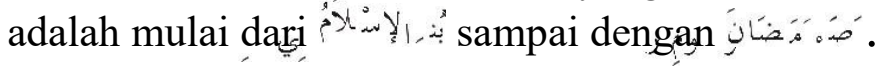

\section{Penelitian Sanad dan Matan Hadits}

\section{Penelitian Sanad}

Setelah Rasulullah Saw wafat, tak pernah ada para sahabat yang me-

T.M. Hasbi Ash-Shiddieqy, Sejarah dan Pengantar Ilmu Hadits, Cet. X, (Jakarta: PT. Bulan Bintang, 1991), h. 192.

Mustafa Zahri, Kunci Memahami Mustalahul Hadits, Cet. II, (Surabaya: PT. Bina Ilmu, 1995), h.13.

T.M. Hasbi Ash-Shiddieqy, loc. cit.

Mustafa zahri, op.cit., h. 14. 
ragukan sahabat yang lainnya. Tabi'in juga tidak pernah ragu mene- rima hadits yang diriwayatkan para sahabat yang mereka terima dari Rasulullah Saw. Nanti setelah fitnah melanda kaum muslimin, muncul seorang Yahudi bernama Abdullah bin Saba' yang menyatakan tuduhan keji yang bertitik tolak pada pemikiran kaum Syiah yang mendewa-dewakan Sayyidina Ali RA. Ia mulai mengadakan infiltrasi terhadap as-sunnah, dan ulahnya itu membekas, dan meningkat pada generasi-generasi berikutnya.

Dari peristiwa tersebut sahabat dan tabi'in bertindak lebih hati-hati dalam menerima dan menyebarkan hadits. Mereka hanya mau menerimanya apabila telah jelas jalan dan rawinya. Mereka mulai meneliti langsung dan merunut nama-nama rawinya apakah jelas terpercaya dan adil atau sebaliknya.

Dalam hal ini terdapat kegiatan penelitian sanad, yakni setelah ke- giatan takhrij dilakukan maka seluruh sanad hadits dicatat dan dihim- pun untuk dilakukan $i$ tibar, Artinya peninjauan terhadap berbagai hal dengan maksud untuk mengetahui sesuatu yang sejenis, dengan menyertakan sanad-sanad yang lain untuk suatu hadits tertentu akan dapat diketahui apakah ada periwayatnya yang adil atau tidak ada un- tuk bagian sanad hadits tersebut.

Menurut Dr. Mahmud al-Tahhan, untuk mempelajari sanad hadits berarti menuntut adanya lima syarat, agar dapat dinilai derajat suatu hadits, yaitu:

a. Mencari biografi perawi

Dalam hal ini para ahli hadits telah berhasil menyusun kitab-kitab tentang biografi perawi dalam berbagai macam susunan (berdasar- kan urutan huruf atau bab-bab fikih), memuat perawi secara umum, biografi perawi tsiqah atau perawi dhaif dan sesamanya. Sehingga itu merupakan keharusan bagi orang yang hendak mengetahui bio- grafi salah satu perwi, untuk melihat kitab-kitab tersebut seperti perawi kitab hadits enam. Jika seorang tidak mengetahui pribadi seorang perawi, ia tetap dapat menemukan biografinya dengan me- ngetahui namanya saja. Karena sebagian besar kitab biografi perawi

Mustafa as-Sibaiy, Hadits sebagai Sumber Hukum Islam, Cet. IV, (Bandung: CV. Diponegoro, 1993), h. 143. 
ini dalam mengemukakan nama-nama perawi menggunakan urutan huruf $m u^{\prime} j a m$ dengan memperhatikan nama perawi dan nama bapaknya.

b. Membahas keadilan dan kedlabitan perawi

Tahap kedua dalam mempelajari sanad hadits adalah meneliti ke- adilan dan kedhabitan perawi dengan cara membaca dan mem- pelajari pendapat para ahli jarh dan $t a$ 'dil yang terdapat di tengah-tengah biografi setiap perawi.

c. Membahas kemuttashilan sanad (sanad yang bersambung)

Dalam hal ini setiap sanad suatu hadits haruslah muttashil atau bersambung. (Lihat contoh hadits pada penjelasan sebelumnya).

d. Membahas syadz dan illat hadits

Membahas syadz dan illat hadits adalah perbuatan yang sangat sulit dibandingkan membahas keadilan dan kedhabitan perawi serta kemuttashilan sanad. Mengetahui ada tidaknya kesesuaian antara beberapa sanad hadits dan menjelaskan ada tidaknya syadz dan illat hadits hanya dapat dilakukan oleh orang yang menguasai (menghapal) banyak sanad dan matan hadits.

Illat hadits dapat dijelaskan dengan cara menghimpun semua $s a$ - nad dan memperhatikan perbedaan perawi hadits.

Berdasarakan uraian di atas bisa diketahui bahwa kegiatan peneli- tian sanad ditempuh melalui jalur seluruh sanad, dalam hal ini harus jelas, sehingga dapat dibedakan antara jalur sanad yang satu dengan jalur sanad yang lainnya. Dan nama-nama periwayat yang dicantumkan harus dicermati, sehingga tidak mengalami kesulitan tatkala dilakukan penelitian melalui kitabkitab rijal. Selanjutnya melihat metode periwayatan yang digunakan oleh masing-masing periwayat.

\section{Penelitian Matan}

Secara umum ada tiga langkah metologis kegeiatan penelitian matan hadits, yaitu:

a. Meneliti matan dengan melihat kualitas sanadnya.

Mahmud al-Tahhan, op.cit., h. 145.

Ibid., h. 152. 
Dalam penelitian hadits, ulama mendahulukan penelitian sanad atas matan. Hal ini bukan berarti bahwa sanad lebih penting dari pada matan. Bagi ulama hadits, dua bagian riawayat hadits itu samasama penting, hanya saja penelitian matan barulah mempunyai arti apabila sanad bagi matan hadits yang bersangkutan telah jelas dan memenuhi syarat. Tanpa adanya sanad, maka suatu matan tidak dapat dinyatakan sebagai berasal dari Rasulullah Saw.

Ulama hadits menganggap penting penelitian matan untuk dilaku- kan, setelah sanad bagi matan itu telah diketahui kualitasnya, da- lam hal ini kualitas shahih, atau minimal tidak termasuk berat ke- dhaifannya. Matan dan sanad yang sangat dhaif tidak perlu diteliti sebab hasilnya tidak akan memberi manfaat bagi kehujaan hadits yang bersangkutan.

b. Meneliti susunan matan semakna.

1) Terjadi perbedaan lafaz

Menurut ulama hadits, perbedaan lafaz yang tidak mengakibat- kan perbedaan makna, asalkan sanadnya samasama shahih, maka hal itu dapat ditoleransi. Cukup banyak matan hadits yang semakna dengan sanad yang sama-sama shahihnya tersusun de- ngan lafaz yang berbeda. Misalnya hadits tentang niat yang ditakhrijkan oleh Bukhari, Muslim, Abu Dawud, Turmudzi, Nasa'i, Ibnu Majah dan Ahmad bin Hambal. Hadits tersebut menurut riwayat Bukhari terdapat tujuh matan yang tersusun lafaznya berbeda-beda.

2) Akibat terjadinya perbedaan lafaz yaitu: menggunakan metode muqaranah (perbandingan)

Dalam hal ini metode muqaranah tidak hanya ditujukan pada lafaz-lafaz matan saja, tetapi juga pada masingmasing sanad- nya, dengan menempuh metode muqaranah, maka akan diketa- hui apakah terjadi perbedaan lafaz pada matan yang masih dapat ditoleransi atau tidak. Metode ini sebagai upaya lebih mencermati susunan matan yang lebih dapat dipertanggungja- wabkan keasliannya. 
c. Meneliti kandungan matan yaitu:

1) Kandungan matan yang sejalan

Untuk mengetahui ada atau tidak adanya matan lain yang memiliki topik masalah yang sama, perlu dilakukan takhrijul hadits $b i$ al-maudhu'. Apabila ternyata ada matan lain yang bertopik sama, maka matan itu perlu diteliti sanadnya. Jika sanadnya memenuhi syarat, maka kegiatan muqaranah perlu dilakukan.

2) Membandingkan kandungan matan yang tidak sejalan

Dalam hal ini jika sejumlah hadits Nabi yang tidak tampak sejalan atau tampak bertentangan dengan hadits lain atau ayat alQuran, maka pasti ada yang melatarbelakanginya. Dalam hal ini digunakan pendekatan-pendekatan yang sah dan tepat se- suai dengan tuntutan kandungan matan yang bersangkutan.

3) Menyimpulkan hasil penelitian

Setelah langkah-langkah di atas ditempuh, maka langkah terakhir dalam penelitian matan ialah menyimpulkan hasil penelitian matan. Karena kualitas matan hanya dikenal dua macam saja, yakni shahih dan dhaif, maka kesimpulan penelitian matan akan berkisar pada dua macam kemungkinan tersebut. ${ }^{10}$

Selanjutnya dalam penelitian matan hadits terdapat beberapa hal, yaitu sebagai berikut:

a. Jika dalam matan hadits terdapat tanda-tanda kepalsuan seperti lemah lafaznya, rusak maknanya atau bertentangan dengan teks alQuran yang shahih atau sebagainya, maka yang tepat untuk mengetahui sumbernya ialah melihat kitab-kitab al-maudhu'at (kitab-kitab tentang hadits maudhu'). Dengan kitab-kitab ini dapat diketahui hadits yang mempunyai sifat-sifat tersebut di atas, semisal takhrijnya, bahasan, dan penjelasan tentang orang yang memalsukannya. Di antara kitab-kitab tentang hadits maudhu' yang disusun berdasarkan huruf hijaiyah adalah al-maudhuah al-kubrah karya Syekh Ali al-Qari al-Harawi, dan kitab yang disusun berdasarkan bab-bab fikih adalah Tanzihu syari'ah al-Marfu'ah

10 H. M. Noor Sulaiman, "Langkah-langkah Penelitian Hadits", dalam Jurnal Hunafa, edisi No. 8, Vol. 3, 1 Desember 2000, STAIN Datokorama Palu, h. 40. 
anil ahadits syaniyah al-maudhu'ah karya Abul Hasan Ali bin Mu- hammad bin Iraq al-Kinany.

b. Jika matan itu termasuk hadits qudsi, maka sumber yang tepat untuk mencarinya adalah kitab-kitab yang khusus menghimpun hadits qudsi, karena di dalamnya disebutkan perawinya secara lengkap. Di antara kitab-kitab tersebut adalah Misyakatul anwar fi ma ruwiyah anillahi subhanahu wa ta'ala minal akhbar, karya Muhyidin Muhammad bin Ali bin Arabi al-Khatimi al-Andalusi, yang mengimpun 101 hadits lengkap dengan sanadnya. Al-Ithafussaniyyah bil ahaditsi qudisiyah, karya Syekh Rauf al-Munawi. ${ }^{11}$

Dalam kaitannya dengan hal di atas, maka menurut jumhur ulama hadits, bahwa tanda-tanda matan hadist yang palsu adalah:

1. Susunan bahasanya rancu. Rasulullah Saw., yang sangat fasih da- lam berbahasa Arab dan memiliki gaya bahasa yang khas, mus- tahil mengeluarkan pernyataan yang rancu tersebut.

2. Kandungan pernyataan bertentangan dengan akal sehat dan sa- ngat sulit ditafsirkan secara rasional.

3. Kandungan pernyataan bertentangan dengan tujuan pokok ajaran Islam, misalnya berisi ajaran untuk berbuat maksiat.

4. Kandungan pernyataan bertentangan dengan sunnatullah (hu- kum alam).

5. Kandungan pernyataan bertentangan dengan fakta sejarah.

6. Kandungan pernyataan bertentangan dengan petunjuk alQuran ataupun hadist mutawatir yang telah mengandung pe- tunjuk secara pasti.

7. Kandungan pernyataannya berada di luar kewajiban diukur dari petunjuk umum ajaran Islam, misalnya: amalan tertentu yang menurut petunjuk umum ajaran Islam dinyatakan sebagai amalan yang tidak seberapa, tetapi diiming-imingi dengan ba- lasan pahala yang sangat luar biasa.

11 Mahmud al-Tahhan, op.cit., h. 92. 


\section{Perkembangan dan pengaruh Sanad terhadap Kla-sfikasi Hadits}

\section{Perkembangan sanad}

Gejala umum yang terdapat dalam sanad hadits adalah semakin jauh orang-orang dari masa Rasulullah Saw., semakin bertambah pula jumlah orang-orang yang meriwayatkan (rawi) hadits dari Nabi Saw. Apabila seorang sahabat misalnya mempunyai sepuluh murid, maka akan kita lihat bahwa jumlah ini pada generasi sesudahnya akan ber- kembang menjadi dua puluh atau tiga puluh dan tersebar di berbagai pelosok negeri Islam. ${ }^{12}$

Berikut akan dikemukakan beberapa contoh untuk menunjukkan betapa menjamurnya sanad.

Contoh pertama, Abu Hurairah melaporkan bahwa Rasulullah Saw bersabda: ketika salah seorang di antara kalian bangun tidur, hendaknya jangan dia memasukkan tangan ke dalam bak mandi/air sebelum dia mencuci tangannya terlebih dahulu tiga kali. Karena seseorang tidak tahu di mana tangannya menetap pada saat dia tidur.

Sekurang-kurangnya ada tiga belas orang murid Abu Hurairah meriwayatkan hadits ini dari beliau, dengan perincian sebagai berikut: delapan orang berasal dari Kufah, dua orang berasal dari Bashrah, satu orang berasal dari Yaman, dan satu orang berasal dari Syiria.

Ada enam orang ahli yang meriwayatkan hadits di atas dari murid Abu Hurairah, dengan perincian sebagai berikut: enam orang berasal dari Madinah, empat orang berasal dari Bashrah, satu orang berasal dari Makkah, Yaman, Kurasan, Syiria, serta dua orang berasal dari Kufah dan Irak. ${ }^{13}$

Contoh kedua, Abu Hurairah melaporkan bahwa Nabi Saw bersabda: Seorang imam harus diikuti apabila dia bertakbir, maka bertakbirlah kalian, apabila dia ruku' maka ruku'lah, jika dia mengatakan sami'allahu liman hamidah maka katakanlah allahumma rabbana lakal hamdu, jika dia sujud, maka sujudlah. Dan sujud sebelum dia

12 M. M. azami, Hadist Nabawi dan Sejarah Kodifikasinya, Cet. I, (Jakarta: Pustaka Firdaus, 1994), h. 548.

13 Muhammad Mustafa Azami, Metodologi Kritik Hadist, Cet. I, (Jakarta: Pustaka Hidayah, 1992), h. 63. 
sujud, dan apabila dia bangun di antara dua sujud maka bangunlah kalian, dan jangan bangun sebelum dia bangun, dan jika dia shalat duduk, maka shalat kalian dengan duduk.

Hadist ini dituturkan oleh dua puluh enam orang generasi ketiga, semuanya mendapat keaslian hadits tersebut langsung dari para saha- bat Nabi Saw. Rangkaian isi hadits tersebut nyaris ditemukan dalam ungkapan yang sama atau arti dan versinya yang mirip, lokasi yang berbeda pada saat itu (Madinah, Makkah, Mesir, Hims, Yaman, Ku- fah, Wasit, dan Thaif). Tiga dari dua puluh enam orang perawi di atas mendengarkan dan mendapatkan hadits tersebut lebih dari satu sumber.

Jalur periwayatannya dari hanya seorang sahabat. Abu Hurairah menggambarkan secara jelas betapa jumlah perawi meningkat dari satu generasi ke generasi berikutnya, dan betapa sebuah hadits menjadi terkenal meluas di tempat yang berbeda. Abu Hurairah paling tidak mempunyai tujuh orang murid yang meriwayatkan hadits ini dari dirinya. Empat orang berasal dari Madinah, dua orang dari Mesir, dan satu orang dari Yaman. Para murid itu setelah pulang ke tempat asal mereka, paling sedikit mempunyai dua belas orang murid lainnya, lima orang dari Madinah, dua orang berasal dari Makkah, satu orang masing-masing dari Syiria, Kufah, Thaif, Mesir, dan Yaman.

\section{Pengaruh sanad terhadap klasifikasi hadist}

Ciri umum dari sebuah hadits shahih di awal bagian abad kedua hijriyah adalah bahwa hadits itu diriwayatkan oleh sejumlah perawi dengan jumlah yang banyak dan berasal dari berbagai provinsi dan negara. Walaupun demikian tidak semua hadits mempunyai satu jalur dalam menyebarluaskan sanad. Kita telah memahami bahwa sejumlah hadits diriwayatkan oleh beberapa orang sahabat dan tabi'in, namun sejumlah hadits lainnya hanya dinukilkan oleh seorang sahabat, kemudian diteruskan juga oleh seorang tabi'in yang hanya mempunyai seorang murid yang meriwayatkan hadits tersebut.

Oleh sebab itu, untuk melihat keberadaan hadits-hadist tersebut dinilai berdasarkan jumlah perawinya. Berdasarkan hal ini, semakin banyak sahabat atau tabi'in yang meriwayatkan hadits itu maka akan 
semakin banyak jalan untuk menuju kepada matan hadits.

\section{E. Penutup}

Berdasarkan uraian yang telah dikemukakan pada bagian terdahulu maka kesimpulan yang dapat ditarik pada bagian penutup ini adalah sebagai berikut:

1. Sanad menurut bahasa berarti sandaran, yang kita bersandar padanya, dan berarti dapat diperpegangi, dipercayai. ${ }^{14}$ Sedangkan menurut istilah, sanad berarti keseluruhan rawy dalam suatu hadits dengan sifat dan bentuk yang ada. Selanjutnya matan menurut bahasa berarti punggung jalan (muka jalan) tanah yang keras

dan tinggi. ${ }^{15}$ Sedangkan matan menurut istilah ialah bunyi atau kalimat yang terdapat dalam hadits yang menjadi isi riwayat. Apakah hadits tersebut berbentuk qaul (ucapan) fi'il (perbuatan, taqrir (ketetapan) dan sebagainya dari Rasulullah Saw.

2. Dalam meneliti sanad sekurang-kurangnya diperlukan lima syarat yaitu: a) mencari biografi perawi, b) membahas keadilan dan ke- dlabitan perawi, c) membahas kemuttashilan sanad (sanad yang bersambung), d) membahas syadz dan, e) membahas illat hadits; selanjutnya dalam meneliti matan maka yang harus diperhatikan adalah: a) meneliti matan dengan melihat kualitas sanadnya, b) me- neliti susunan matan yang semakna, dan c) meneliti kandungan matan.

3. Perkembangan dan pengaruh sanad terhadap klasifikasi hadits pada gejala umum dapat diklasifikasi bahwa sanad pada tingkat sahabat jumlahnya lebih sedikit dibanding pada tingkat tabi'in dan pada tingkat tabi'in lebih sedikit dibanding dengan tingkat tabi' 'it-tabi' in dan seterusnya sampai pada tingkat jumlah yang cukup banyak.

14 T.M. Hasbi Ash-Shiddieqy, Sejarah dan Pengantar Ilmu Hadits, Cet. X, Jakarta: PT. Bulan Bintang, 1991, h. 192.

15 T.M. Hasbi Ash-Shiddieqy, loc. cit. 


\section{Daftar Pustaka}

Azami, M. M., Hadist Nabawi dan Sejarah Kodifikasinya, Cet. I, (Jakarta: Pustaka Firdaus, 1994).

Azami, Muhammad Mustafa, Metodologi Kritik Hadits, Cet. I, (Jakarta: Pustaka Hidaya, 1992).

Global Islamic Software Company, al-Hadits al-Syarif, al-isdarutstsany, jamiu al-huquqy mahfudzatu lisyirkatial-muramij alislamiyah al-Dauliyah, 1991-1997, Hadits Shahih Bukhari.

Ash-Shiddieqy, T.M. Hasbi, Sejarah dan Pengantar Ilmu Hadits, Cet. X, (Jakarta: PT. Bulan Bintang, 1991).

As-Sibaiy, Mustafa, Hadits sebagai Sumber Hukum Islam, Cet. IV, (Ban- dung: CV. Diponegoro, 1993).

Sulaiman, H. M. Noor, "Langkah-langkah Penelitian Hadits", dalam Jurnal Hunafa, edisi No. 8, Vol. 3, 1 Desember 2000 STAIN Datokorama Palu.

Al-Tahhan, Mahmud, Ushul al-Takhrij wa darasah al-asanid, diterjemah- kan oleh Ridwan Nasir dengan judul Metode Takhrij dan Penelitian Sanad Hadits, (Surabaya: PT. Bina Ilmu, 1995).

Zahri, Mustafa, Kunci Memahami Mustalahul Hadits, Cet. II, (Surabaya: PT. Bina Ilmu, 1995). 